\title{
2001 Bhuj-Kachchh earthquake: surface faulting and its relation with neotectonics and regional structures, Gujarat, Western India
}

\author{
James P. McCalpin $\left({ }^{1}\right)$ and Mahesh G. Thakkar $\left(^{2}\right)$ \\ (1) GEO-HAZ Consulting Inc., Crestone, CO, U.S.A. \\ $\left(^{2}\right)$ Department of Geology, Shri R.R. Lalan College, Bhuj, Kachchh (Gujarat), India
}

\begin{abstract}
Primary and secondary surface deformation related to the 2001 Bhuj-Kachchh earthquake suggests that thrusting movement took place along an E-W fault near the western extension of the South Wagad Fault, a synthetic fault of the Kachchh Mainland Fault (KMF). Despite early reconnaissance reports that concluded there was no primary surface faulting, we describe an $830 \mathrm{~m}$ long, $15-35 \mathrm{~cm}$ high, east-west-trending thrust fault scarp near where the seismogenic fault plane would project to the surface, near Bharodiya village (between $23^{\circ} 34.912^{\prime} \mathrm{N}$, $70^{\circ} 23.942^{\prime} \mathrm{E}$ and $23^{\circ} 34.304^{\prime} \mathrm{N}, 70^{\circ} 24.884^{\prime} \mathrm{E}$ ). Along most of the scarp Jurassic bedrock is thrust over Quaternary deposits, but the fault scarp also displaces Holocene alluvium and an earth dam, with dips of $13^{\circ}$ to $36^{\circ}$ south. Secondary co-seismic features, mainly liquefaction and lateral spreading, dominate the area south of the thrust. Transverse right-lateral movement along the «Manfara Fault» and a parallel fault near Bharodiya suggests segmentation of the E-W master faults. Primary (thrust) surface rupture had a length of $0.8 \mathrm{~km}$, maximum displacement of about $35 \mathrm{~cm}$, and average displacement of about $15 \mathrm{~cm}$. Secondary (strike-slip) faulting was more extensive, with a total end-to-end length of $15 \mathrm{~km}$, maximum displacement of $35 \mathrm{~cm}$, and average displacement of about $20 \mathrm{~cm}$.
\end{abstract}

Key words surface rupture - Kachchh earthquake thrust fault

\section{Introduction}

The 2001 Bhuj-Kachchh earthquake was one of the largest events in the Stable Continental Regions (SCR) of the world. Comparable events are the New Madrid earthquakes of 1811-1812, the Charleston earthquake of 1886, and the 1819 Kachchh (Allah Bund) earthquake (fig. 1).

Mailing address: Dr. James P. McCalpin, GEO-HAZ Consulting Inc., P.O. Box 837, Crestone, CO 81131 U.S.A.; e-mail: mccalpin@geohaz.com
Therefore, the 2001 Bhuj-Kachchh earthquake $\left(M_{w}\right.$ 7.7) is an important event for the comparative study of two big earthquakes in the same tectonic province.

Kachchh has a long history of earthquakes and has experienced two major events and tens of smaller events within the past 200 years. The vast wastelands and salty playas are probably the result of a few major earthquakes in the past 3000-4000 years. The nature and the dates of all those earthquakes, except the 1819 event and its penultimate event (Rajendran et al., 1998; Rajendran and Rajendran, 1999, 2001; Rajendran, 2000), are yet to be known. In the present paper we attempt to relate the nature of the 2001 Bhuj earthquake with the regional structures, especially with the 


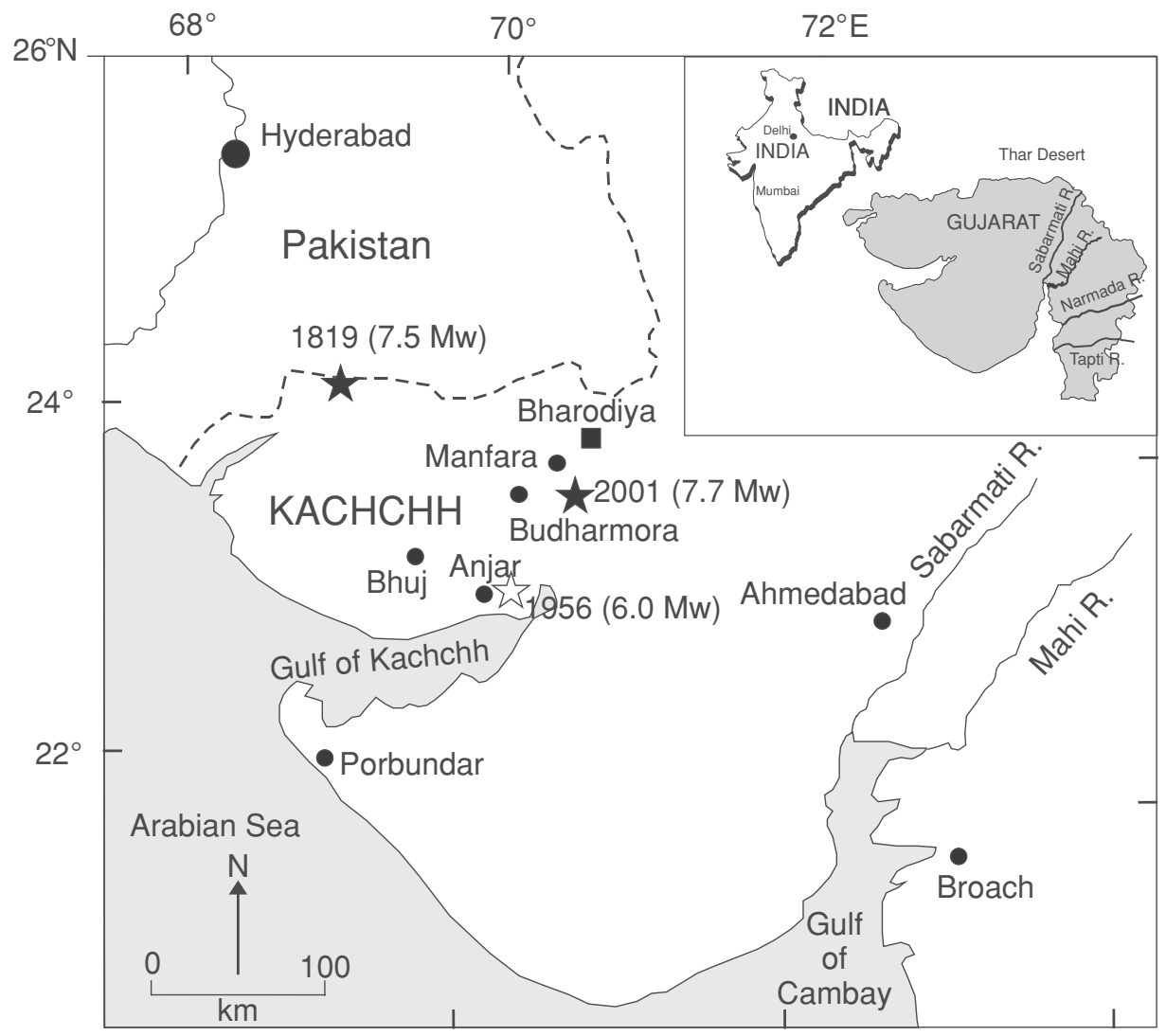

Fig. 1. Location map showing epicenters of the 26 January 2001 and 1819 Allah Bund earthquakes, and villages mentioned in the text.

Quaternary morphotectonic features along the major E-W and transverse fault systems. A unique model is also proposed herein to show segmented movement on the E-W oriented active faults, with NE-SW, NW-SE, NNESSW or NNW-SSE transverse faults being the limit of the individual blocks, during the 2001 earthquake.

This paper is the result of 2 weeks of field mapping in May 2001, during which time the authors traced surface ruptures on the ground and mapped them with GPS. In addition we excavated one exposure of the thrust fault in a streambank and logged another trench excavated by a previous French reconnaissance team.

\subsection{Geomorphology}

The geomorphology of Kachchh is influenced by its regional tectonic setting and is dominated by the basin bounding master faults and main axis of the basin which runs WSW (Biswas, 1981). Each physiographic division of Kachchh is flanked by a major structural feature. There are four physiographic divisions identified, the Ranns, the low-lying Banni plain, the hilly regions and the southern coastal plain (fig. 2a). The Ranns are vast flat regions covered with a fairly hard salt encrustation. These are the areas of large continental, recent sedimentary basins rising not more than $4 \mathrm{~m}$ above msl. The Little Rann is an extension of 
the gulf of Kachchh when the sea level was high during the Holocene transgression. The Great Rann of Kutch is bounded by the Nagar Parker Fault on the north and the Island Belt Fault and the Plain of Banni (a low alluvial tableland between the Mainland of Kachchh and the Great Rann) on the south. The Banni is a smooth and nearly flat saline grassland.

The uplifted hilly region of Kachchh consists of three uplifts: 1) 4 separate anticlines that compose the Island Belt Fault Zone; 2) the Kachchh Mainland uplift, and 3) the Wagad uplift. The Island Belt Fault Zone comprises four «islands», viz. Pachchham, Khadir, Bela and Chorar, controlled and separated by the right-lateral transverse and strike-slip faults. The northern boundaries of these «islands» are controlled mainly by the Island Belt Fault, where steep scarps and colluvial fans are common. The table-like region with low dip due south and southwest of Khadir and Bela Islands is known as the Wagad Highland. The Kachchh Mainland uplift is composed of rocky terrain having two sub-parallel E-W trending hill ranges; the Katrol Hill range in the middle and the dome-dominated northern hill range. The Mainland also comprises a strip of coastal plain in the south.

\subsection{Regional structure and tectonics}

Rifting at the western margin of the Indian plate was controlled by the NE-SW trend of the Delhi (Pre-Cambrian) fold belt that swings to $\mathrm{E}-\mathrm{W}$ in Kachchh. The E-W striking master faults are resurgent basement faults (Biswas, 1987) that controlled the structural style of the basin. In the post rifting stage, Kachchh was under a compressional regime when the foot-

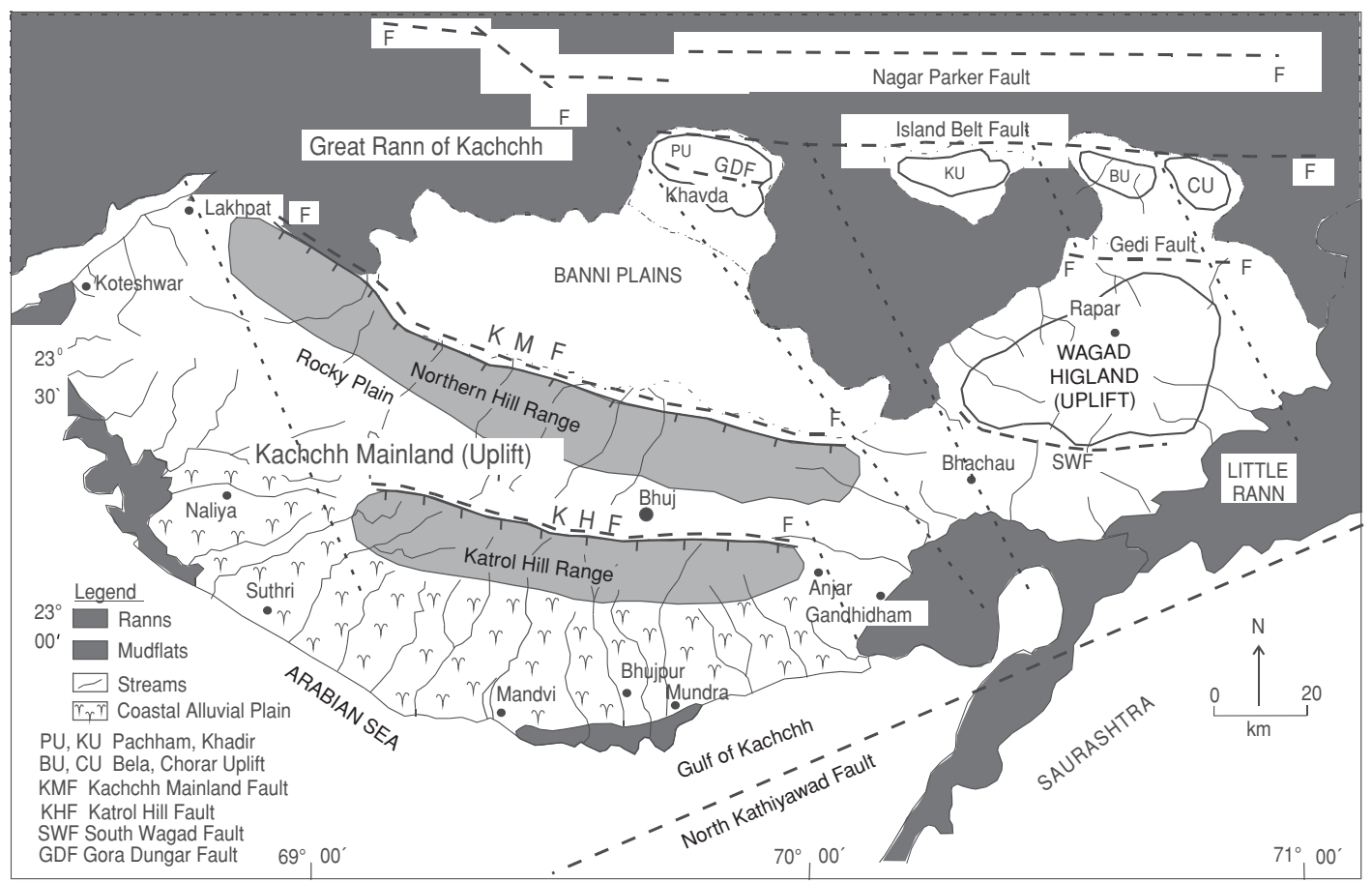

Fig. 2a. Map showing major geomorphic subdivisions, mountain fronts, and Late Cenozoic faults on the mainland of Kachchh. KMF = Kachchh Mainland Fault. 
wall blocks uplifted along the E-W master faults and formed the highlands, and intervening half-grabens formed the plainlands. It is during this stage the blocks tilted towards south, and therefore the nature of the master faults also changed from normal to reverse and strike slip. The uplifts are oriented E-W along five parallel faults: 1) Nagar Parkar Fault; 2) Island Belt Fault; 3) South Wagad Fault (SWF); 4) Kachchh Mainland Fault (KMF); 5) North Kathiawar Fault (NKF) (fig. 2a). In addition to the E-W striking master faults, the associated uplifts are extensively affected by oblique secondary faults of later age. The secondary faults trend NE-SW or NW-SE and offset the primary faults, so are termed transverse strike slip faults.

\subsection{Neotectonics}

Systematic study of Quaternary tectonic activity in Kachchh was begun only in the past decade, so there is no sizable amount of work available. However, Thakkar et al. (1999) and Maurya et al. $(2002,2003)$ constructed a Quaternary stratigraphy and tectonic evolution of mainland Kachchh, respectively. Quaternary tectonic uplift took place in two major phases. The Early Quaternary tectonic activity took place along the E-W trending faults while the Late Pleistocene phase took place along the NNE-SSW to NNW-SSE trending transverse faults. The E-W trending faults were more active during Early Quaternary, as evidenced by miliolites overlapping the colluvial deposits along the Katrol Hill Fault (Thakkar et al., 1999). This geometry suggests that the present configuration of the landscape came into being during the Early Quaternary due to differential uplift along E-W faults, viz. the KMF and KHF (fig. 2a). The Early Quaternary physiographic setting has been modified by the Late Pleistocene-Holocene tectonic activity along transverse faults (Thakkar et al., 2001).

The Kachchh region has experienced large and moderate earthquakes in historic times. The 1819 Kachchh earthquake $\left(M_{w} 7.5\right)$ is the largest event to have occurred in the Rann of Kachchh near the India-Pakistan border during historic time, and the 1956 Anjar earthquake $\left(M_{w} 6.0\right)$ is the largest during the instrumental period. The
Anjar event was located nearly $40 \mathrm{~km}$ west of the epicenter of the 2001 event. It originated at a focal depth of $15 \mathrm{~km}$ and is believed to have occurred on the KMF (one of the southern boundary of the Kachchh rift), whereas the 1819 earthquake occurred on the northern boundary of the Kachchh rift about $140 \mathrm{~km} \mathrm{NW}$ of the 2001 event. Morphological evidence of maximum uplift of about $6 \mathrm{~m}$ in 1819 showing a northerly slope suggests that it was associated with thrust motion on a north-dipping fault (Oldham, 1926; Bilham, 1998; Rajendran and Rajendran, 1999). Apart from the major events, minor earthquakes are also recorded in the area and appear to cluster along the active fault lines.

Neotectonic landforms of the area suggest that most large Holocene earthquakes have occurred along transverse faults. Malik et al. (1999) concluded that the seismicity of Mainland Kachchh was confined to the KMF and KHF, but a large number of epicentral plots of earthquakes of historic period compiled by them around Bhuj show distinct clustering around transverse faults, indicating that the latest phase of tectonic activity was more along the transverse faults. Thakkar et al. (1999) suggested that the compressive stresses accumulating on the E-W latitudinal faults of Mainland Kachchh, due to locking up of the Indian plate in the NE, are transmitted to the NNE-SSW and NNW-SSE transverse faults. The change in tectonic environment from extensional to compressional is also responsible for the activity of transverse strike-slip faults in Kachchh. The focal mechanism of the 2001 Bhuj and 1956 Anjar earthquakes suggested by USGS also indicates tectonic reversal in the region. The stress field oriented in the N-S to NNE-SSW direction is considered to be responsible for this reversal of movement and the ongoing deformation (Rajendran et al., 2001).

\section{The 26 January, 2001 Bhuj earthquake}

The 26th January 2001 Bhuj earthquake is the most disastrous earthquake in the post-instrumental era in India. The 2001 Bhuj earthquake originated at 08:46:41 IST with the focal depth of $22 \mathrm{~km}$ and a magnitude of $7.7 M_{w}$, with the epicenter located at $23.36^{\circ} \mathrm{N}, 70.34^{\circ} \mathrm{E}$ (Bendick 
et al., 2001; our fig. 1). The number of lives lost during 2001 Bhuj earthquake exceeded 25000 and nearly 200000 people were injured. About 400000 houses suffered severe to complete damage and twice as many were partially damaged. According to the preliminary analysis of part of the aftershock data collected by the Middle America Earthquake Center, the coseismic fault plane dips $40^{\circ}-50^{\circ}$ south. Projection of this plane to the surface predicts an intersection $7-8 \mathrm{~km}$ north of Bharodiya village.

Kayal et al. (2002) concluded that the best located aftershocks define two major fracture directions, one trending $\mathrm{NE}$ and the other NW, and the ruptures meet at a zone $10 \mathrm{~km}$ south of main shock epicenter. Further, Kayal et al. (2002) obtained two well constrained solutions for two clusters of aftershocks at the mid-crustal depth. The NW cluster of events shows pure reverse faulting with SW dipping, NW-SE-striking preferred fault plane, and a NE cluster shows reverse faulting with a large strike-slip component on SE dipping, NE-SW-striking fault plane.

This earthquake generated huge liquefaction and related deformational features in the epicentral area around Bhachau (Jain and Lettis, 2001; Singh et al., 2001; Tuttle et al., 2002). The Ranns and the plains of Banni, being made up of unconsolidated Holocene sediments, served as vast grounds for liquefaction. The liquefaction was mainly concentrated along the concealed major faults of the region. It was accompanied by lateral spreads, sand blows, and water spouts, mainly between the Khadir Uplift and the eastern part of the Mainland Uplift. Complete documentation of all liquefaction and related features in the Ranns was very difficult, because the area is too marshy with the quick sands, which under liquefaction become dangerous to travel across. However, Rajendran et al. (2001) documented many of the features and provide the best postearthquake study.

\section{Primary surface faulting}

Rajendran et al. (2001) concluded that primary surface deformation possibly existed $2 \mathrm{~km}$ north of Bharodiya village, in what we refer to herein as the Northern Dextral Fault Zone (fig. 2b). We began our reconnaissance at a NWtrending «monocline» in this fault zone, first observed by Arch Johnston and Paul Bodin of CERI in February 2001, and later visited on February 18-19, 2001 by C.P. and K. Rajendran, M. Thakkar, and Tish Tuttle (Rajendran et $a l ., 2001)$. From the «monocline» we continued northwest and southeast, following a N3040W-trending, $0.9 \mathrm{~km}$ long Northern Dextral Fault Zone (described later under Secondary Surface Deformation).

The right-lateral faulting continued to about $23^{\circ} 34.697^{\prime} \mathrm{N}, 70^{\circ} 24.572^{\prime} \mathrm{E}$, at which point the rupture zone abruptly turned west and became a $830 \mathrm{~m}$ long, east-west-striking, north verging thrust fault (fig. 3). Because this scarp has the same orientation and sense of slip as the mainshock, and exists close to where the mainshock plane would project to the surface, we treat it as primary surface faulting. The eastern $320 \mathrm{~m}$ of the thrust lies at the base of a low E-W bedrock ridge underlain by Jurassic sandstone (Wagar Formation), and the remainder crosses an alluviated plain. At the eastern end of the thrust, faults are short (10-30 m long) and en échelon, and expose bedrock on both the hanging wall and footwall. Small tent structures and articulated monoclines (fig. 3) are common, as if the 2001 surface displacement was insufficient for the south-dipping thrust plane to break cleanly to the surface. In places a small north-dipping backthrust existed at the crest of the monocline.

Most of the thrust scarp at the base of the bedrock ridge was developed in thin sandy colluvium or slopewash, and ranged from a sinuous trace to a linear trace (fig. 4). Scarp height varied from 15 to $25 \mathrm{~cm}$. The most common scarp morphology was a hanging wall collapse scarp, where the overhanging tip of colluvium failed after (or during) thrusting (see McCalpin, 1996, p. 193). The thrust scarp continues another $135 \mathrm{~m}$ west of the bedrock ridge, and then is truncated by a N20E-striking, $30 \mathrm{~m}$ long right stepover zone of dextral faults and tension cracks. Average displacement in the stepover is $20 \mathrm{~cm}$ right-lateral (fig. 3).

West of the stepover the thrust crosses a plain underlain by thicker alluvial deposits, and the height and sinuousity of the scarp increase 


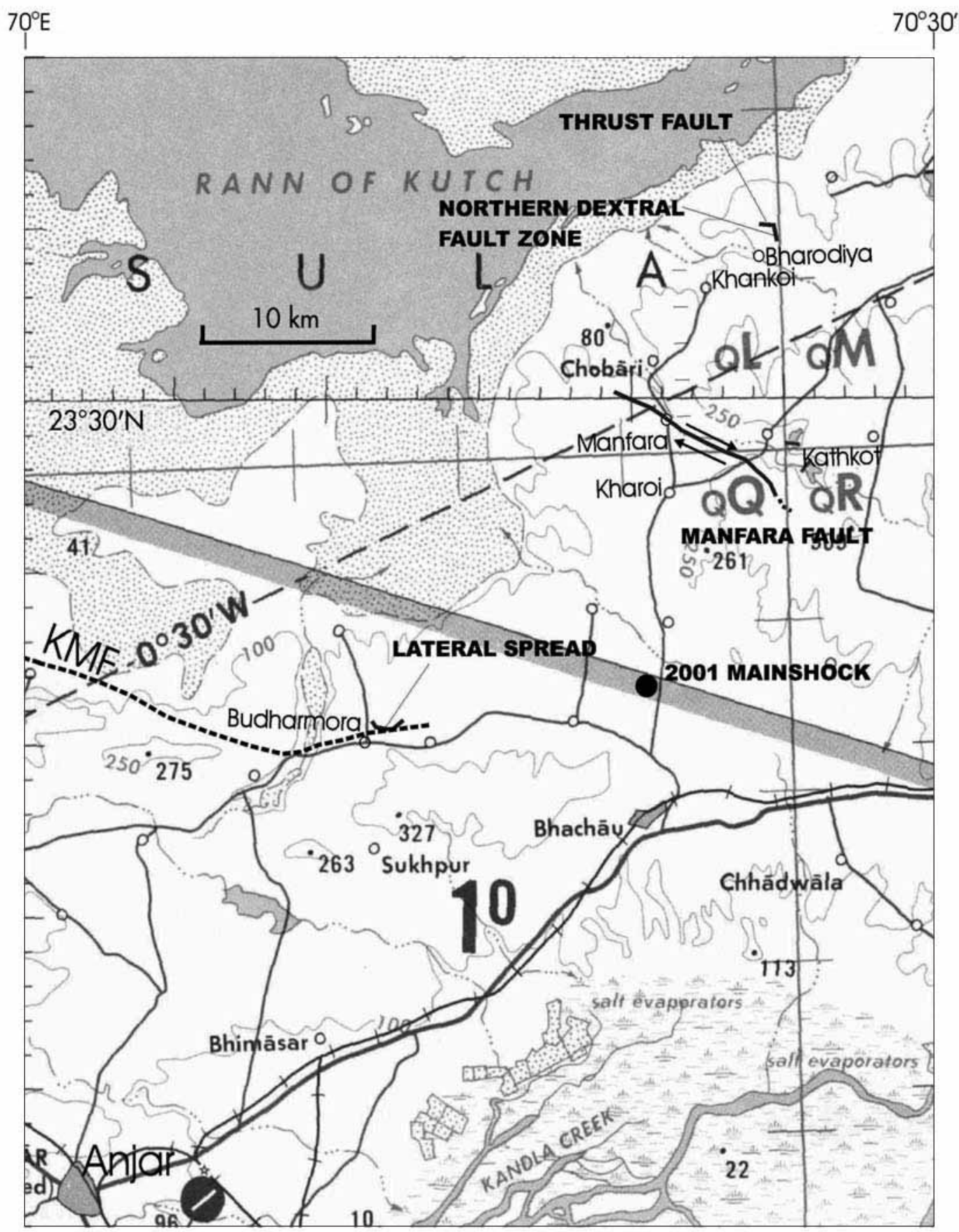

Fig. 2b. Detailed map showing location of 2001 surface faulting and lateral spreading (thicker gray lines with associated bold labels). KMF = Kachchh Mainland Fault. 


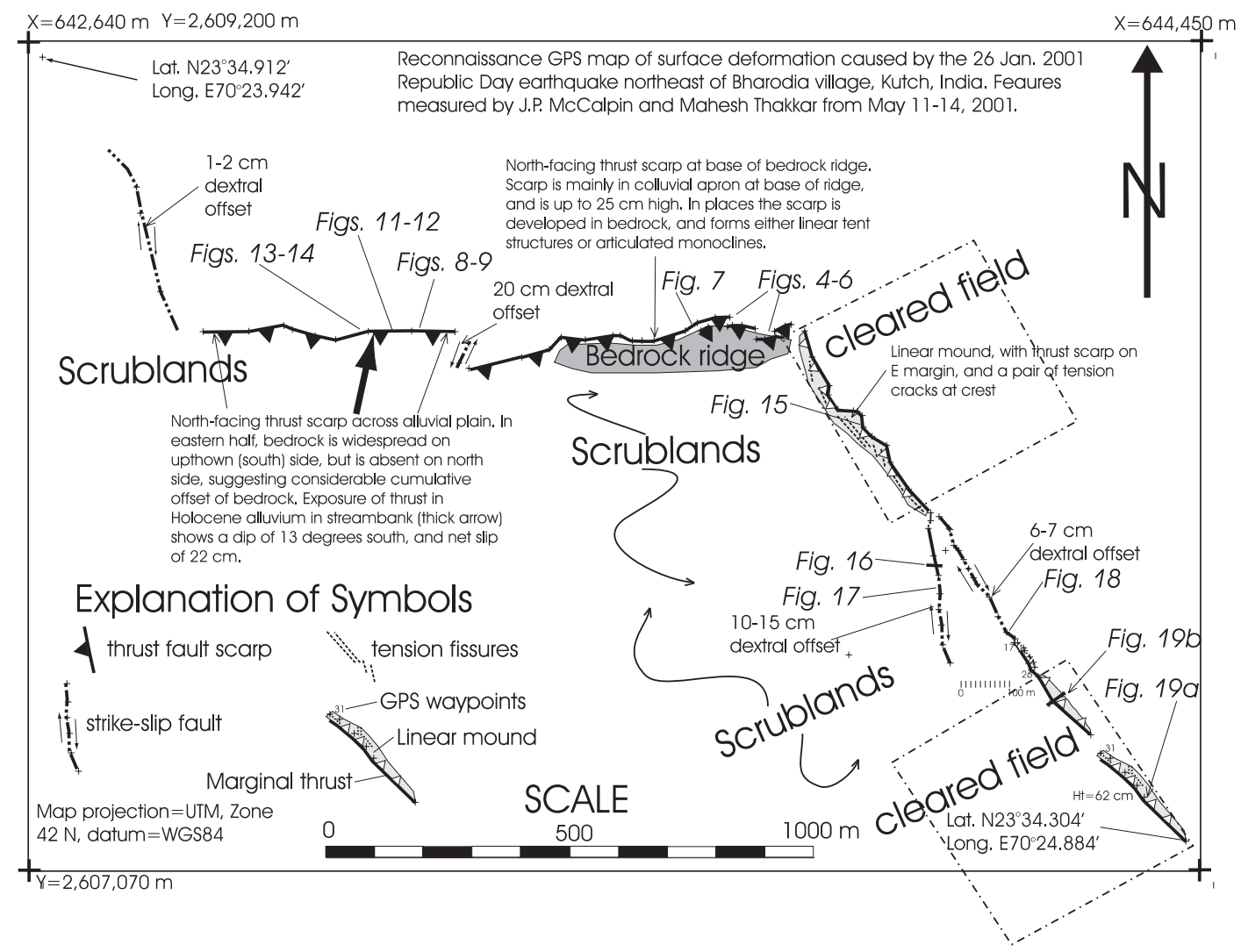

Fig. 3. Reconnaissance GPS map of surface faulting north of Bharodiya village. The northwest-trending fault zones on either end display dextral slip, whereas the east-west-trending, $1.2 \mathrm{~km}$ long scarp between them displays northward thrusting with a small dextral component. We classify the thrust faulting as primary faulting and the strike slip faulting as secondary (tear) faulting, following Seeber et al. (2001). Total length of surface faulting is $2.6 \mathrm{~km}$ (measured between the ends) or $3.0 \mathrm{~km}$ (measured along the fault).

(fig. 5). The most common scarp morphologies here are: 1) sinuous hanging wall collapse scarp; 2) tent structures, and 3) less sharp moletracks. The upthrown (south) side of the scarp is characterized by horizontal Jurassic bedrock at the surface, whereas north of the scarp bedrock is buried everywhere by Quaternary deposits of unknown thickness. These observations indicate that the total vertical separation of bedrock across the fault is significantly greater than the $15-25 \mathrm{~cm}$ of throw in 2001, and presumably resulted from prehistoric fault movements, which are as yet unstudied.

\subsection{Exposure of the 2001 thrust in a Streambank}

About $275 \mathrm{~m}$ west of the bedrock ridge (at $\mathrm{N} 23^{\circ} 34.70^{\prime}, \mathrm{E} 70^{\circ} 24.21^{\prime}$ ), the 2001 thrust scarp crosses a 1-1.5 m deep stream channel and the fault plane is exposed in the western streambank (fig. 6). The fault cuts Late Pleistocene and Holocene (?) fluvial deposits and creates a 22 to $25-\mathrm{cm}$ high mole track on the surface with tent structures. The thrust dips $13^{\circ}$ south and displaces a small channel margin (late Pleistocene/Holocene contact?) with a net 


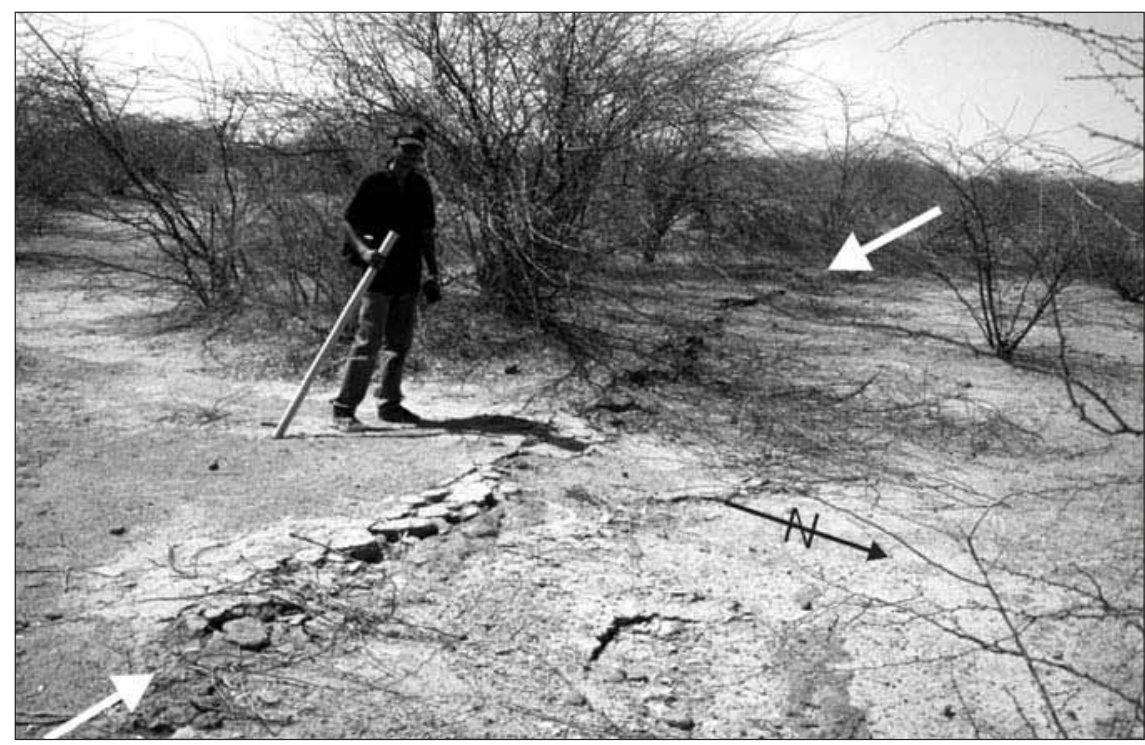

Fig. 4. Straight section of thrust scarp (between white arrows) near eastern end of the rupture, at $23^{\circ} 34.695^{\prime} \mathrm{N}$, $70^{\circ} 24.413^{\prime} \mathrm{E}$ view to southwest. Scarp is developed in thin sandy alluvium overlying Jurassic sandstone.

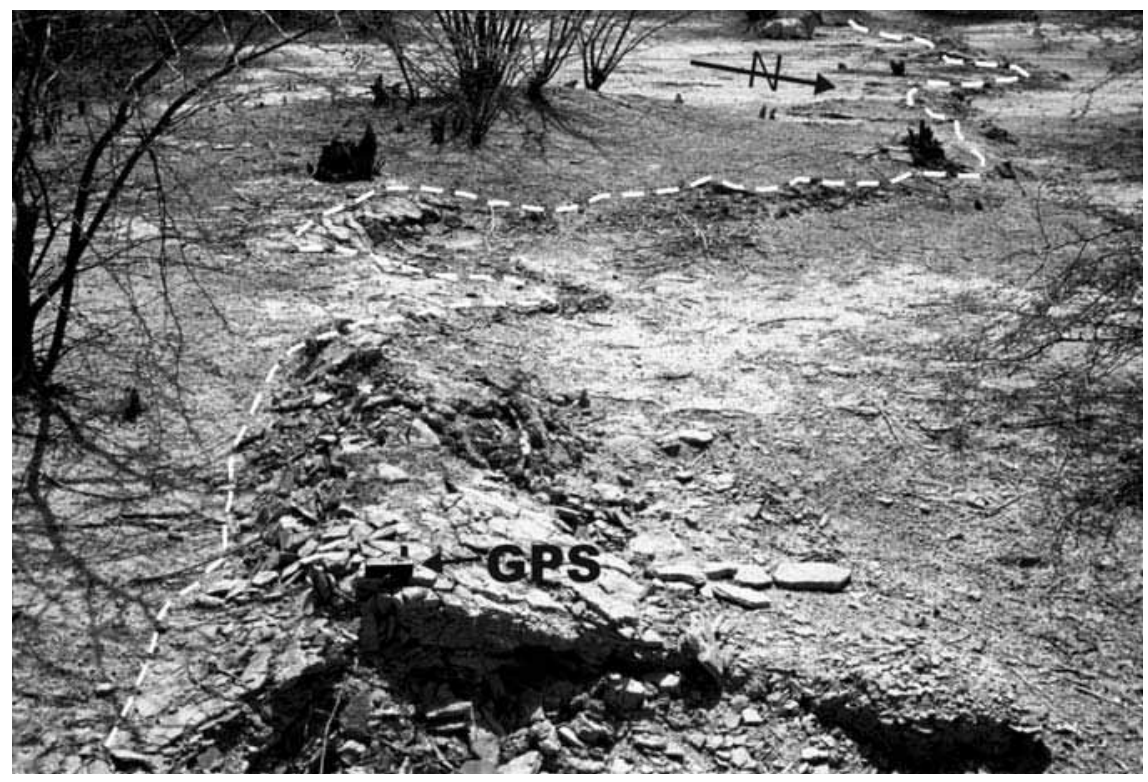

Fig. 5. Sinuous thrust scarp west of the bedrock ridge; white dashed line follows the scarp crest. Note cow for scale in far distance to left of dashed line. Faulted material here is a thicker Quaternary sandy alluvium that contains a hardpan soil profile about $30 \mathrm{~cm}$ thick. The tent structure in the foreground $\left(\right.$ at $23^{\circ} 34.699^{\prime} \mathrm{N}, 70^{\circ} 24.282^{\prime} \mathrm{E}$ ) was formed by horizontal compression and breakage of the hardpan layer. Scarp height ranges from 20 to $30 \mathrm{~cm}$. View to the west. 


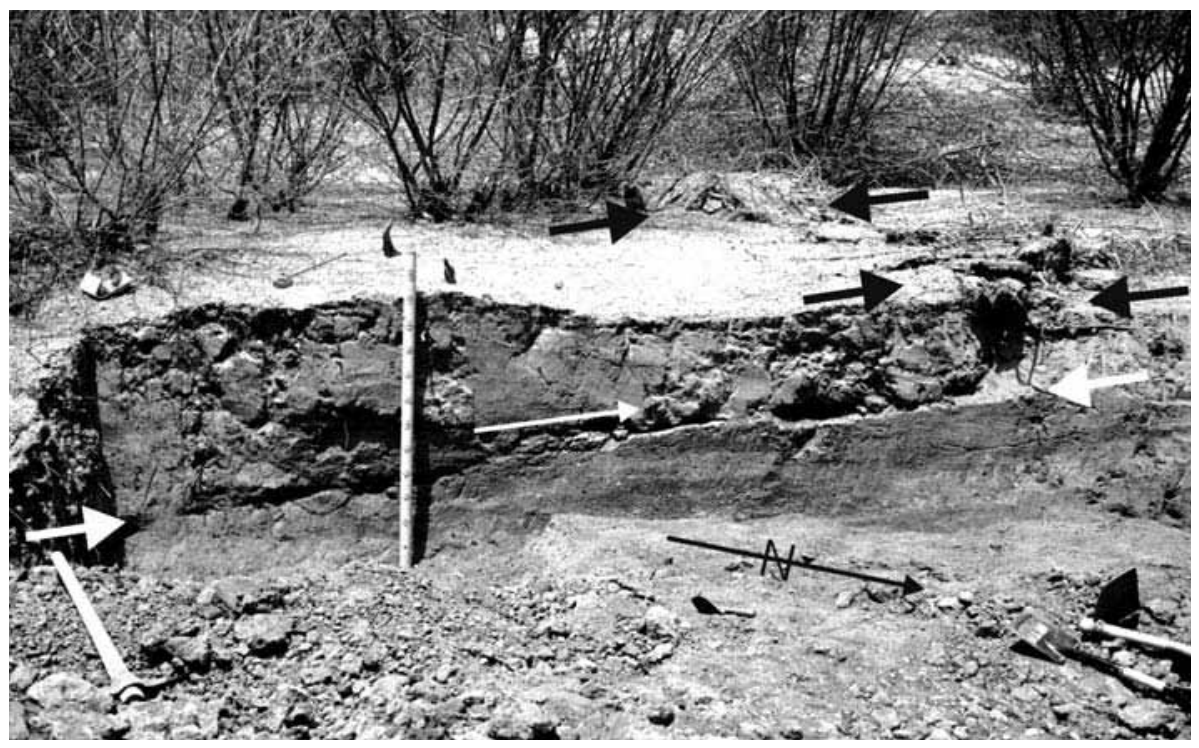

Fig. 6. Exposure of the thrust fault in a streambank at $23^{\circ} 34.700^{\prime} \mathrm{N}, 70^{\circ} 24.210^{\prime} \mathrm{E}$. The 2001 thrust fault (between thick white arrows) dips $13^{\circ}$ south and the sense of movement is shown by the thin white arrow. At the bottom of the hardpan layer the fault steepens to subvertical, probably following a subvertical crack caused by ground shaking, and creates a tent structure.

slip of $22 \mathrm{~cm}$ (fig. 7). This fortuitous exposure permitted us to observe how tent structures were created by low-angle thrusting and how their dimensions are related geometrically to fault slip (see next section).

From the streambank exposure the sinuous thrust scarp continues west, characterized by moletracks and hanging wall collapse scarps $15-30 \mathrm{~cm}$ high. About $120 \mathrm{~m}$ west of the streambank the scarp continues up and over a northtrending, $2.3 \mathrm{~m}$ high earth dam (fig. 8) and forms a degraded scarp at its crest $20 \mathrm{~cm}$ high. The fault trace migrates $3.25 \mathrm{~m}$ northward as it climbs the $2.3 \mathrm{~m}$ high embankment, resulting in an apparent dip of about $36^{\circ}$ south. This angle is considerably steeper than that observed in the streambank.

From the dam the thrust scarp continues west as a sinuous hanging wall collapse scarp or moletrack (fig. 9). Individual thrust scarp lobes have a wavelength of 5-10 m and an amplitude of 2-3 $\mathrm{m}$ in plan view. In this area thrust scarps reach their greatest height $(27-35 \mathrm{~cm}$, at $\left.23^{\circ} 34.701^{\prime} \mathrm{N}, 70^{\circ} 24.073^{\prime} \mathrm{E}\right)$. Farther west the thrust scarp/moletrack dies out and is replaced by a N20W-trending zone of small and widely spaced dextral cracks. These dextral cracks average 1-2 cm of net slip and are about $50 \mathrm{~m}$ long, after which they step left and form a small north-facing thrust scarp or moletrack of similar length. Northwest of about $23^{\circ} 34.812^{\prime} \mathrm{N}$, $70^{\circ} 24.019^{\prime} \mathrm{E}$ even the dextral cracks vanish, and we were unable to find further surface faulting, despite a lengthy search.

\subsection{Displacement estimates from tent structures}

It was difficult to measure displacement on the 2001 thrust fault because vertical exposures were rare. Our first estimates assumed that a fault plane dipping south at $15^{\circ}$ to $35^{\circ}$ had created a simple thrust scarp $15-35 \mathrm{~cm}$ high, which implied a net slip vector ranging from $26 \mathrm{~cm}$ ( $35^{\circ}$ fault dip and $15 \mathrm{~cm}$ high scarp) to $135 \mathrm{~cm}$ 
Log of streambank across thrust scarp, $\mathrm{N}$ of Bharodia, India

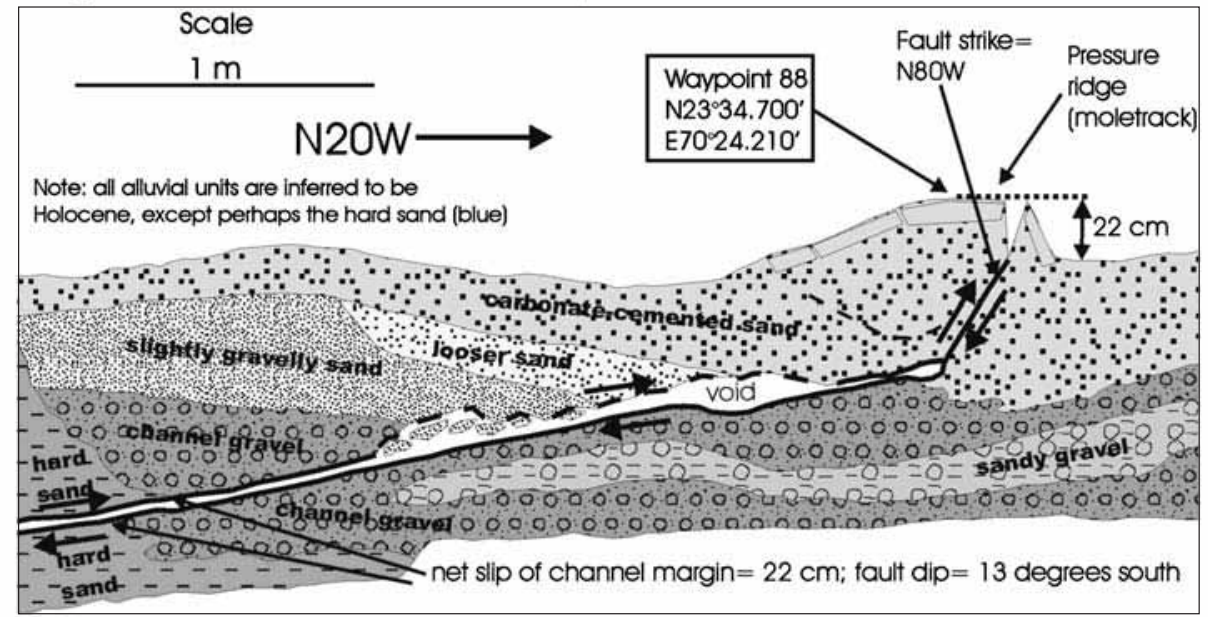

Fig. 7. Log of the streambank exposure.

( $15^{\circ}$ fault dip and $35 \mathrm{~cm}$ high scarp). This wide discrepancy shows the difficulty in making an accurate net slip estimates solely from scarp height. However, the streambank exposure showed that the low-angle thrust fault did not continue propagating at $13^{\circ}$ once it hit the base of the hardpan layer (carbonate-cemented sand on fig. 7), but instead steepened to subvertical, probably following a subvertical crack created during earthquake shaking of the hardpan. This refraction of the fault plane created head-on compression of the broken hardpan layer, resulting in upward arching of hardpan slabs and the resultant tent structure.

Based on the streambank exposure, we propose a simple geometric model that relates horizontal tectonic shortening to the surface dimensions of the tent structure (fig. 10). We observed that the ground surface in the tent structure is uplifted and tilted but not horizontally compressed, and inelastic deformation appears limited to thickening of the hardpan layer in the tent structure. Therefore, the amount of horizontal shortening $(D)$ can be related to the tent structure as follows:

$$
D=2(L-(L \cos \alpha))
$$

where $D=$ horizontal shortening; $L=$ length of one limb of the tent structure; $\alpha=$ dip angle of the limb.

The height of the tent structure is given by

$$
Z=L \sin \alpha
$$

where $Z=$ height of the tent structure.

For example, $5 \mathrm{~m}$ west of the streambank exposure (where net slip was $22 \mathrm{~cm}$ on a $13^{\circ}$ dipping fault) is a symmetrical tent structure with $Z=25 \mathrm{~cm}$ and $L=40 \mathrm{~cm}$. According to eq. (3.2), the dip of the limbs is $39^{\circ}$. Entering that value into eq. (3.1), we can compute a horizontal shortening of $18 \mathrm{~cm}$. This compares with $21 \mathrm{~cm}$ of horizontal shortening observed in the streambank exposure. The value computed from the tent structure is much smaller than the net slip required for an unrefracted $13^{\circ}$ dipping fault to create a scarp $25 \mathrm{~cm}$ high. In contrast, the computed $18 \mathrm{~cm}$ of horizontal shortening is only $15 \%$ smaller than the value measured in a vertical cut, which suggests that a small amount of inelastic shortening (crushing?) did occur in hardpan layer in the tent structure. Farther east, the tent structure shown in fig. 5 is asymmetrical, with a right (north) limb of $L=90 \mathrm{~cm}$ and 


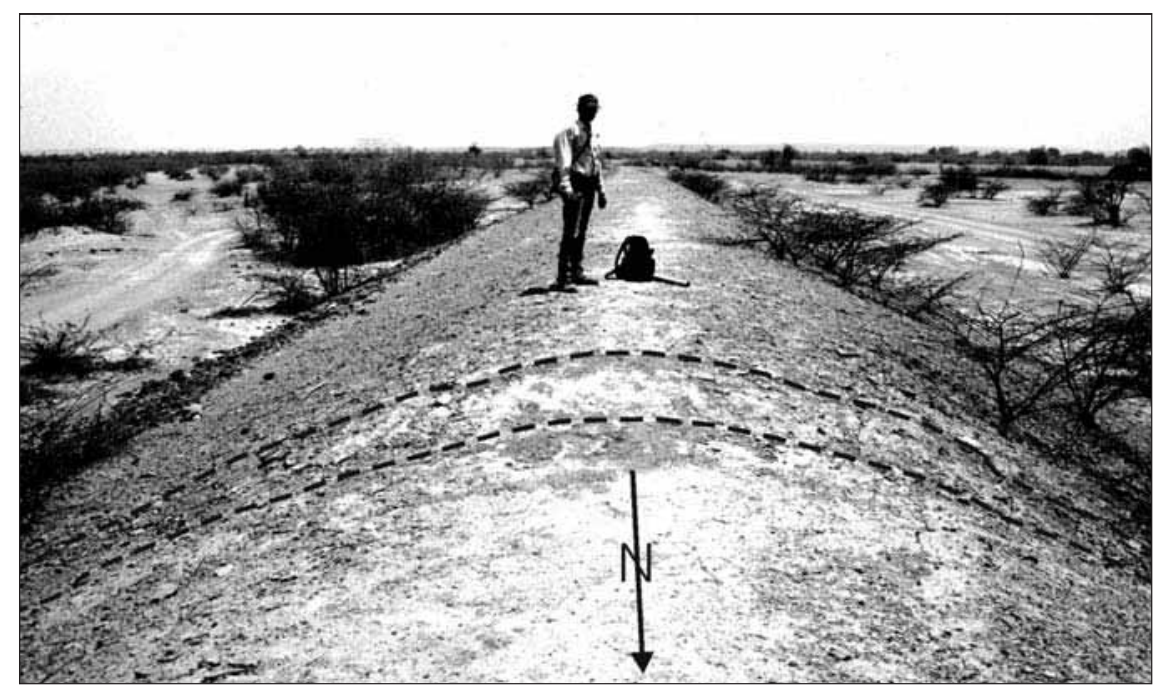

Fig. 8. Thrust scarp (between dashed lines) crossing the axis of a north-south-trending, $2.3 \mathrm{~m}$-high earth dam (dike), at $23^{\circ} 34.705^{\prime} \mathrm{N}, 70^{\circ} 24.140^{\prime} \mathrm{E}$. The scarp reaches a maximum height of $20 \mathrm{~cm}$ at the dam crest, and is slightly higher on the western side of the crest than on the eastern side, implying a small component of dextral slip in addition to north-directed thrusting. The apparent dip of the fault as it ascends the east side of the earth dam is $36^{\circ}$ south.

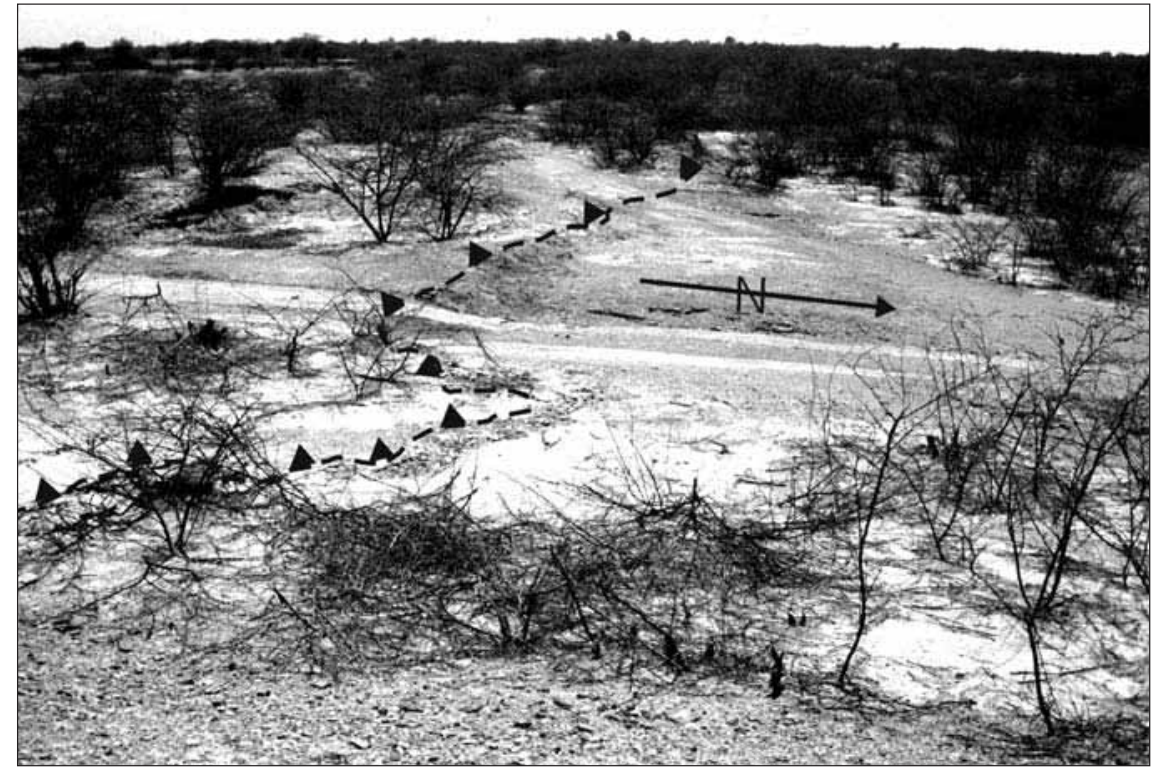

Fig. 9. Photograph of the sinuous trace of the thrust scarp west of the dam shown in fig. 11a,b. View is to the west from the crest of the earth dam. Dashed line follows the crest of the scarp. Thrust crosses a faint road road in upper center at $23^{\circ} 34.701^{\prime} \mathrm{N}, 70^{\circ} 24.111^{\prime} \mathrm{E}$. 


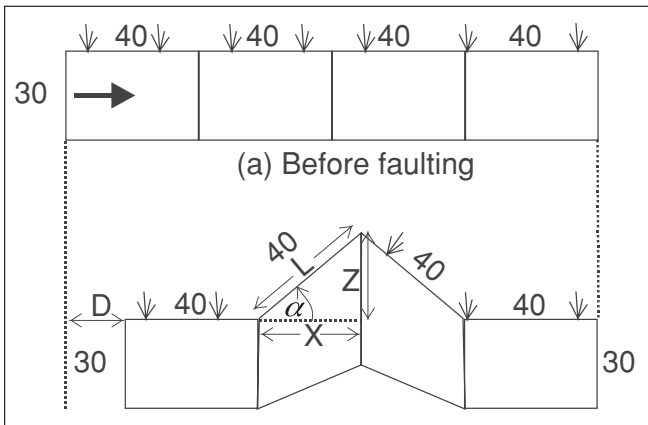

(b) After faulting

Fig. 10. Schematic diagrams showing the geometry of an idealized tent structure. (a) Hardpan layer is $30 \mathrm{~cm}$ thick and is arbitrarily divided into four $40 \mathrm{~cm}$ long sections. (b) Hardpan layer is subjected to horizontal shortening $(D)$, which creates a tent structure with height $(Z)$, half-length $(L)$, and limb dip angle $(\alpha)$. After shortening, field observations show that the length of each $40 \mathrm{~cm}$ long section remains constant at ground level. Thus, the tented sections must thicken as shown, in order to conserve volume (this also minimizes the space problem below the center of the tent structure). The horizontal distance $X$ beneath each half of the tent structure is now less than $40 \mathrm{~cm}$, by half the amount of horizontal shortening $(D / 2)$. In this example, dimensions are taken from the streamcut locality on the thrust fault northwest of Bharodia village (fig. 6), where $W=40 \mathrm{~cm}$ and $Z=25 \mathrm{~cm}$, resulting in a computed slab dip angle $(\alpha)$ of $39^{\circ}$ and computed horizontal shortening of $18 \mathrm{~cm}$. Equations in the text describe relationships between $D, W, X, Z$, and $\alpha$.

$\alpha=25^{\circ}$. Applying eq. (3.1) there predicts horizontal shortening of $17 \mathrm{~cm}$.

\subsection{Summary of primary surface faulting}

The $830 \mathrm{~m}$ long thrust scarp described previously clearly resulted from tectonic faulting, because it involves bedrock, crosses natural and man-made topography indiscriminately, and is not associated with any gravitational failures such as lateral spreads. Scarp morphology (hanging wall collapse scarps, moletracks, tent structures) is similar to that of primary surface ruptures during other thrust earthquakes (Philip et al., 1992; McCalpin, 1996). However, at this time we cannot prove that this thrust scarp is the surface expression of the 26 January mainshock plane, or even that the thrust was produced during the mainshock, rather than during an aftershock between 26 January and 11 May 2001, when we began our reconnaissance. Therefore, the scarp has several possible origins:

a) is the surface expression of the 26 January mainshock plane;

b) represents shaking-triggered slip on a preexisting fault updip from the 26 January mainshock plane (i.e. induced displacement);

c) is the surface expression of an aftershock plane;

d) represents shaking-triggered slip on a preexisting fault updip from an aftershock plane (i.e. induced displacement).

Based on our limited reconnaissance we favour origin (a), but cannot rule out origins (b) through (d) without further detailed study.

\section{Secondary surface faulting}

Several post-earthquake reconnaissance teams observed NW-trending dextral surface faults east of the mainshock epicenter. Their orientation (NW) and sense of slip (right lateral) do not match the focal mechanism of the 26 January mainshock (northward thrusting on an east-west plane), but they were apparently formed wholly or partly during the mainshock. Seeber et al. (2001) concluded that the longest of these faults, the $8 \mathrm{~km}$ long Manfara Fault (next section), was a secondary tear fault that bounded the eastern margin of the north-thrusted block. Accordingly, we describe two zones of dextral faulting below. The first zone (the northern dextral fault zone) was discovered and mapped by us from May 11-14, 2001, $2 \mathrm{~km}$ north of Bharodiya village, and the second is the Manfara Fault described by Seeber et al. (2001).

\subsection{The northern dextral fault zone near Bharodiya village}

North of Bharodiya village, Rajendran et al. (2001) first described an elevated zone of unknown origin $80 \mathrm{~m}$ long, $10 \mathrm{~m}$ wide and 80 
$\mathrm{cm}$ high, gently dipping towards the northeast. We traced this zone to its northwest and southeast terminations from May 11-14, and found that it connects with the eastern end of the thrust scarp described previously. This «northern dextral fault zone» trends $\mathrm{N} 30^{\circ}-40^{\circ} \mathrm{W}$ (fig. 3 ) and is composed of: 1) a $325 \mathrm{~m}$ long northern section of east facing linear mounds, that intersects the eastern end of the primary thrust scarp; 2) a 310 $\mathrm{m}$ long central dextral fault zone, and 3) a $275 \mathrm{~m}$ long southern section of west-facing, linear mounds. Both linear mounds exist on the edges of cultivated fields and their surface geometry (described below) may have been influenced by the presence of the fields.

The northern linear mound section trends $\mathrm{N} 35^{\circ} \mathrm{W}$ and parallels the western edge of a cultivated field (fig. 11a,b). The mound is up to $0.6 \mathrm{~m}$ high and $6-12 \mathrm{~m}$ wide and is asymmetrical, bounded by a slightly sinuous thrust scarp on its steeper eastern side and by a more gentle, monoclinal fold on its western side. Large tension cracks up to $5 \mathrm{~cm}$ wide and $1.1 \mathrm{~m}$ deep exist on the mound crest and trend

(a)

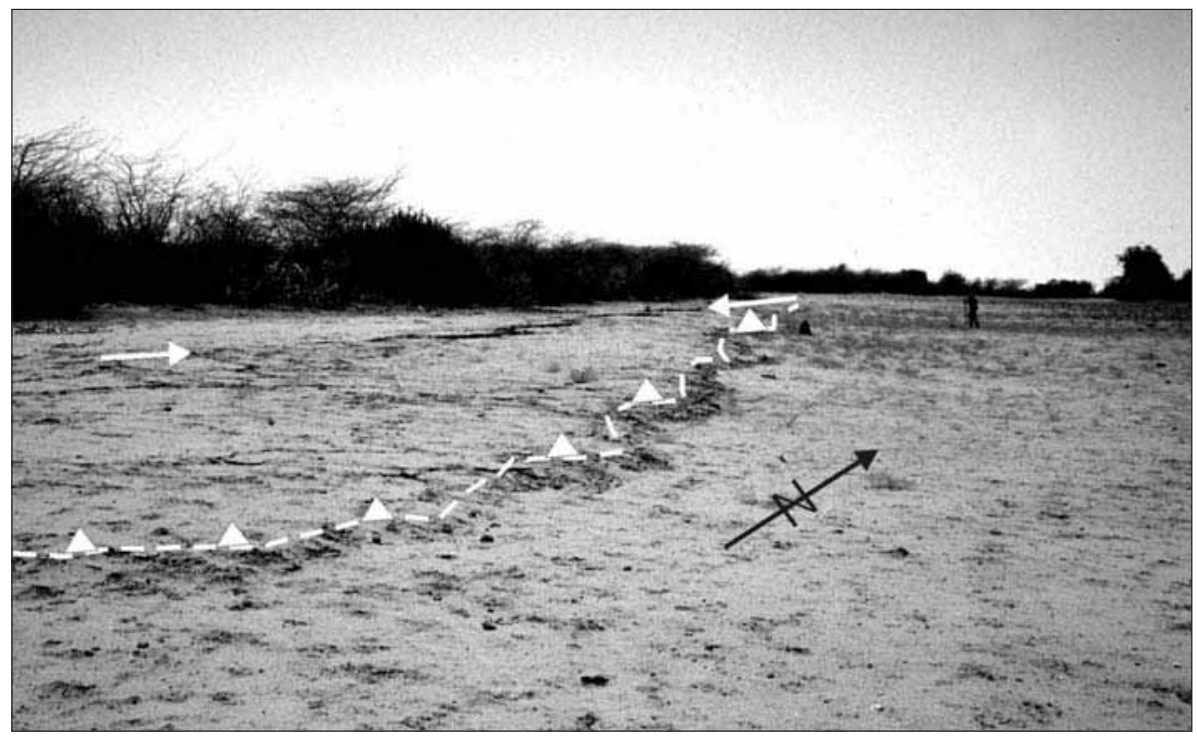

(b)

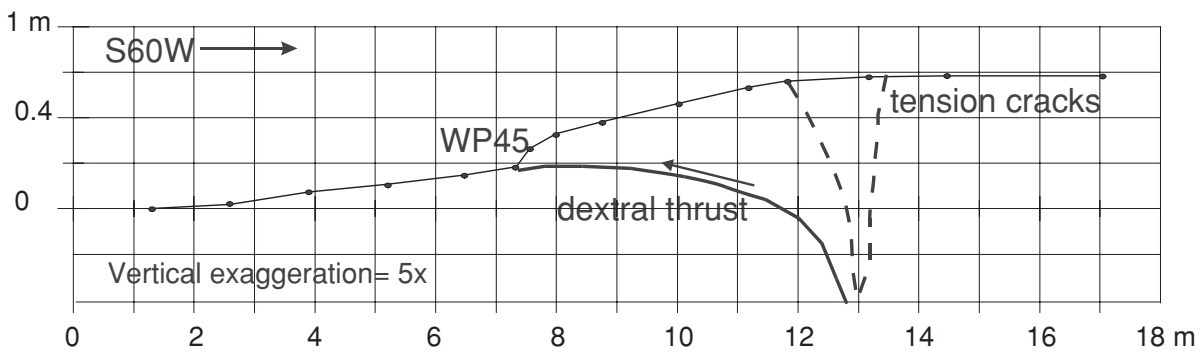

Fig. 11a,b. Southern part of the northern linear mound zone. a) Photograph of the mound looking northwest. White dashed line follows the crest of the thrust scarp that bounds the mound on the east. White arrows show axial tension cracks. Small black pack to right of scarp in center, and to left of standing figure, is at $23^{\circ} 34.575^{\prime} \mathrm{N}$, $70^{\circ} 24.657^{\prime} \mathrm{E}$. b) Topographic profile across the mound at the site of the pack, with subsurface structures inferred. Note vertical exaggeration of $5 x$. Total height of the mound ranges from 40 to $60 \mathrm{~cm}$. 
$\mathrm{N} 20 \mathrm{~W}$, or about $15^{\circ}-20^{\circ}$ more westerly than the mound itself. The sinuousity of the thrust scarp lobes varies from south (wavelength of 4.5-5.5 m, amplitude of 1.5-2 $\mathrm{m}$ in plan view) to north (wavelength 8-12 m, amplitude 2-3 m in plan view).

The $310 \mathrm{~m}$ long central dextral fault zone coincides with uncultivated, native scrubland and is dominated by dextral faults, but also contains small, parallel thrust scarps and small linear mounds. At the road crossing in its northern part, the zone is composed of a $22 \mathrm{~cm}$ high thrust scarp on the west, and $30 \mathrm{~m}$ to the east, a parallel zone of dextral cracks with $7-10 \mathrm{~cm}$ displacement. This is the only place where the dextral-reverse slip is partitioned between two discrete, parallel faults. Directly south of the faulted road (fig. 3), the dextral fault zone trends N-S and is composed of en échelon, leftstepping, $\mathrm{N} 20^{\circ}$ E-striking dextral cracks joined by small thrust faults (fig. 12). Total dextral offset across this zone is $10-15 \mathrm{~cm}$.
The southern part of the dextral rupture zone is characterized by a low $(15-33 \mathrm{~cm}$ high), broad (6-12 m wide) linear mound (fig. 13a,b). The mound is bounded on the west by a sinuous, low, degraded thrust scarp (7-20 cm high) and on the east by a weak monocline. Fresh tension cracks with apertures $3-6 \mathrm{~cm}$ wide run down the axis of the mound. The tension cracks were not observed on February 18-19, 2001 by Rajendran et al. (2001), and cut through slopewash deposits from a rainstorm of April 12-15. Thus, although the mound and its degraded thrust scarp were probably formed during the 26 January 2001 mainshock, the axial tension cracks must have resulted from some aftershocks between April 15 and May 11, when we first observed them.

The $275 \mathrm{~m}$ long southern linear mound section trends $\mathrm{N} 35 \mathrm{~W}$ along the eastern edge of a cultivated field, and is composed of two linear mounds that trend $\mathrm{N} 45 \mathrm{~W}$ and step right. The northern part of this section comprises the

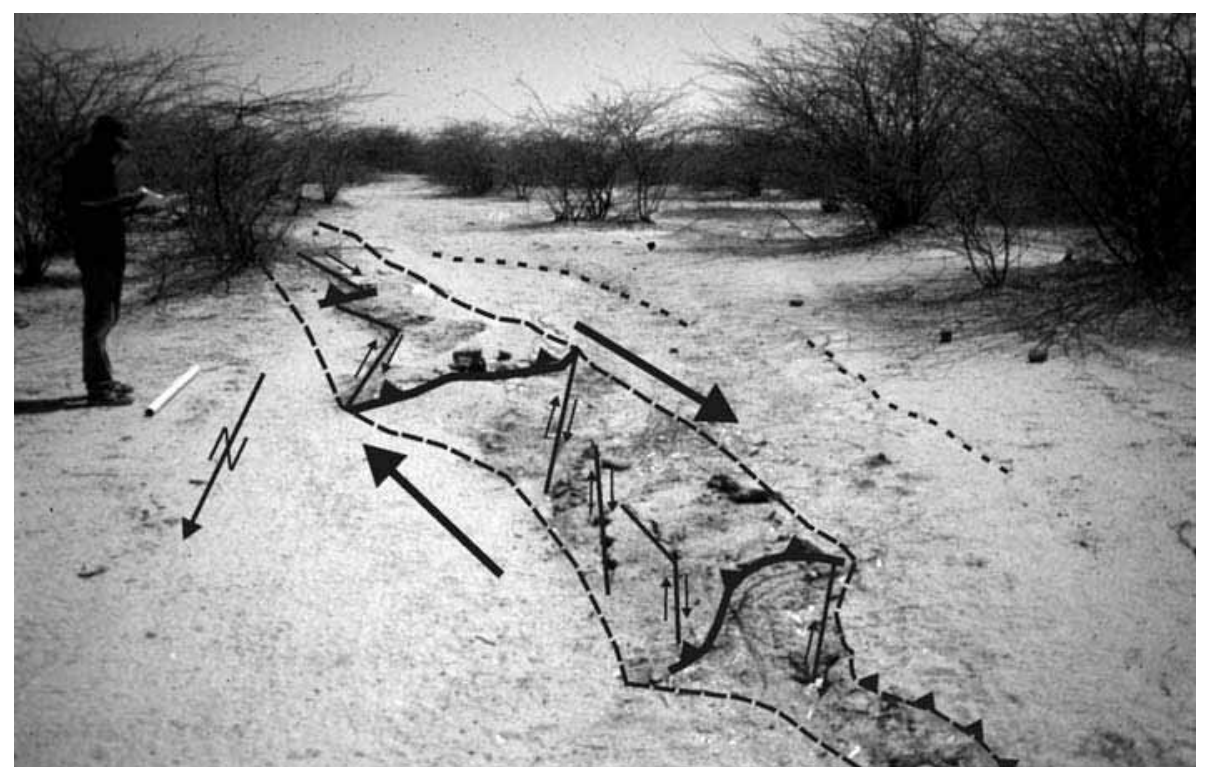

Fig. 12. Strike-slip fault zone (between dashed lines) south of the road shown in fig. 3; view is to south. The surface rupture is composed of a system of left-stepping dextral cracks that trend oblique to the strike of the fault zone. At each left step a small north-verging thrust fault is formed (thick black line, teeth on upthrown block). Largest thrust at center is at $23^{\circ} 34.495^{\prime} \mathrm{N}, 70^{\circ} 24.682^{\prime} \mathrm{E}$. At lower right the rupture becomes a thrust scarp which continues to road shown in fig. 15. 
(a)
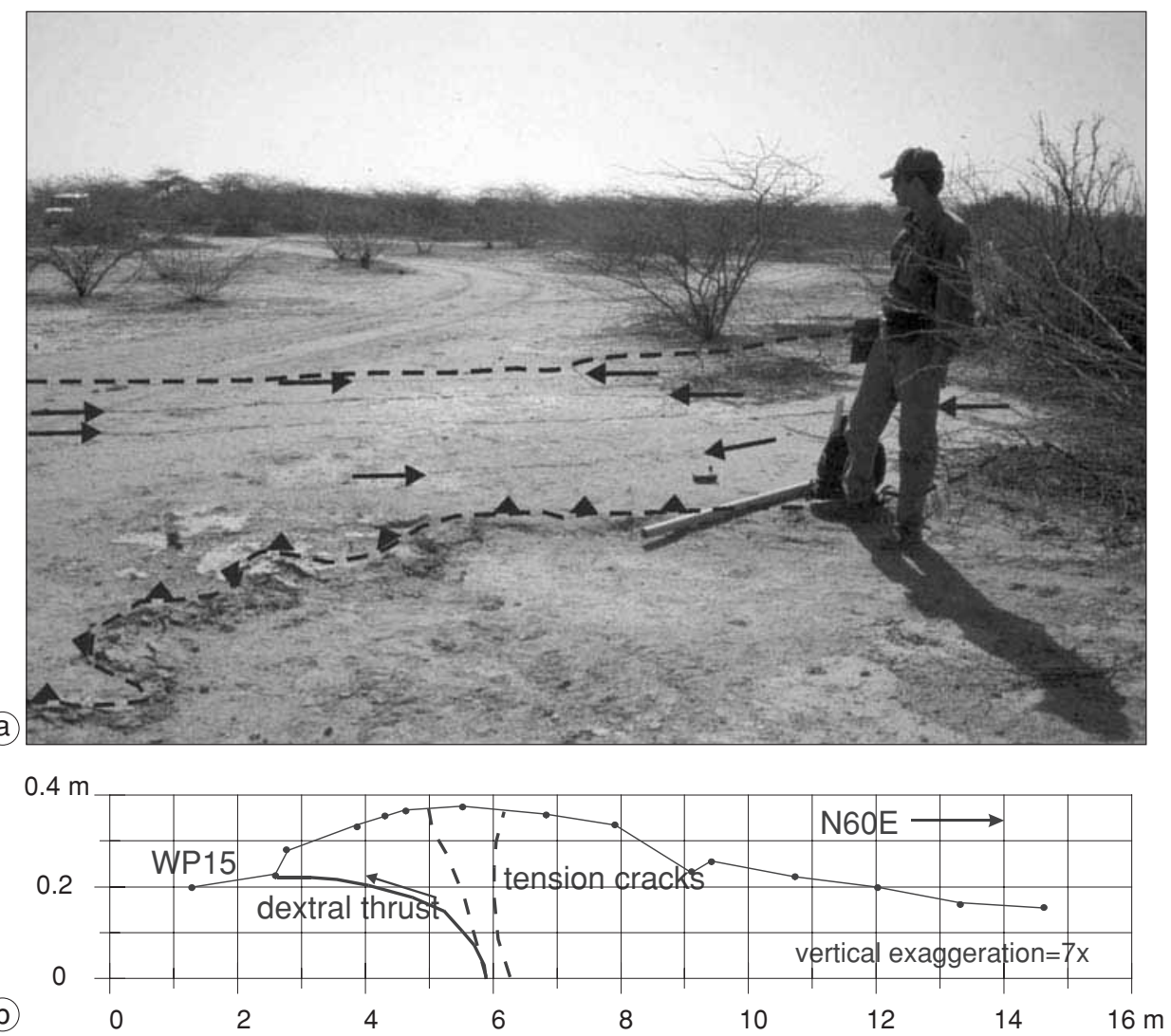

Fig. 13a,b. The welt north of the southern plowed field, at $23^{\circ} 34.465^{\prime} \mathrm{N}, 70^{\circ} 24.737^{\prime} \mathrm{E}$. a) Photograph of the N30W-trending welt, looking east. The welt is $16 \mathrm{~cm}$ high and $6.3 \mathrm{~m}$ wide here, bounded on the west by a sinuous, $7.5 \mathrm{~cm}$, high thrust scarp (dashed line, teeth on upthrown block) and on the east by a smoother monocline (dashed line). Arrows show axial tension cracks, $3-5 \mathrm{~cm}$ wide. b) Topographic profile across the welt, with subsurface structures inferred. Note the large vertical exaggeration required to show the welt's shape.

«monocline» described by Rajendran et al. (2001) and is about $100 \mathrm{~m}$ long. This asymmetrical linear mound is $0.6 \mathrm{~m}$ high and $12 \mathrm{~m}$ wide, bounded by a slightly sinuous thrust scarp on its steeper western side and by a more gentle, monoclinal fold on its eastern side. In other words, it faces the opposite direction to the northern linear mound, and faces the cultivated field. In the center of this section is a stepover zone $30 \mathrm{~m}$ long that contains no visible deformation. South of the stepover is another linear mound $170 \mathrm{~m}$ long, $75 \mathrm{~cm}$ high at its northern end, and $62 \mathrm{~cm}$ high at the southern boundary of the field, which slowly dies out southeast of the field. This mound has the same asymmetry as the «monocline» mound, but unlike the that mound, also contains axial tension cracks $10-15 \mathrm{~m}$ long, some of which had vented liquefied sand.

The linear mounds represent a new style of surface deformation previously unreported in SCR earthquakes, but due to lack of exposures we are unsure exactly what type of structures underlie them. Because the rupture that crosses unmodified terrain shows $15-20 \mathrm{~cm}$ of dextralreverse offset, and because other NW-trending faults such as the Manfara Fault show similar 


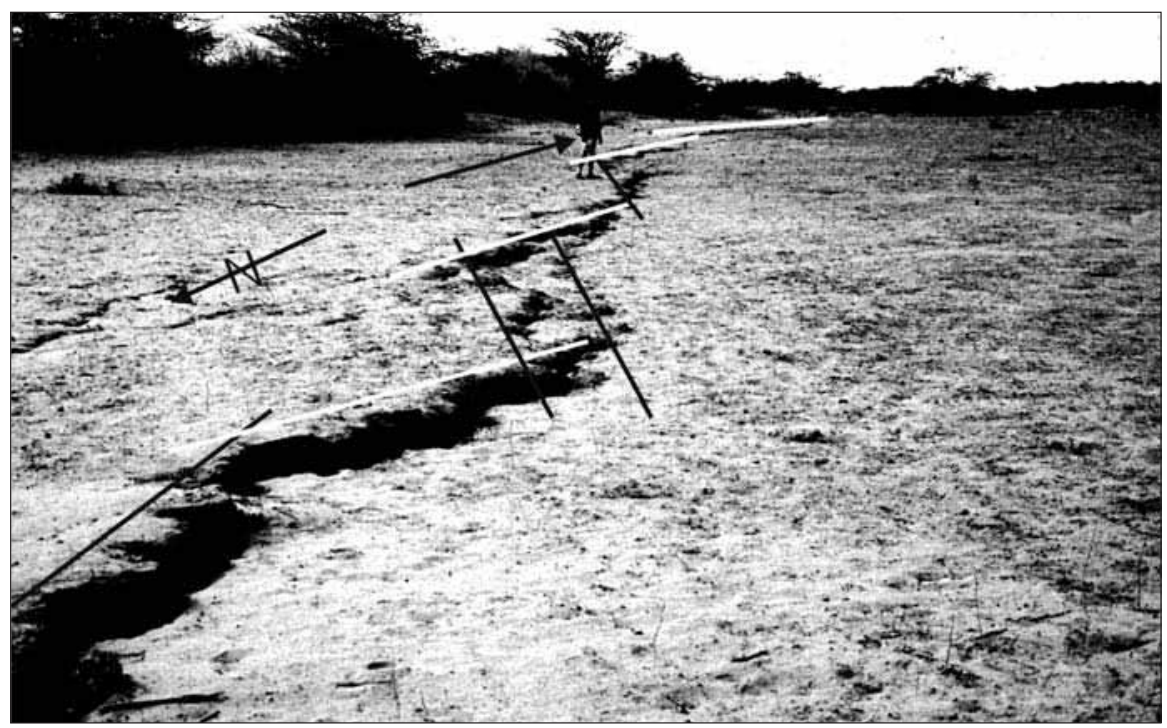

Fig. 14. The southern part of the Manfara Fault, south of the highway that runs northeast from Kharoi; view to the southeast. The dextral displacement here is $32 \mathrm{~cm}$ accompanied by $19 \mathrm{~cm}$ of vertical component, east side up. The rupture trace trends N15W and is composed of alternating longer dextral scarp segments trending N35E (white lines) slip and shorter extensional segments trending N20W (black lines).

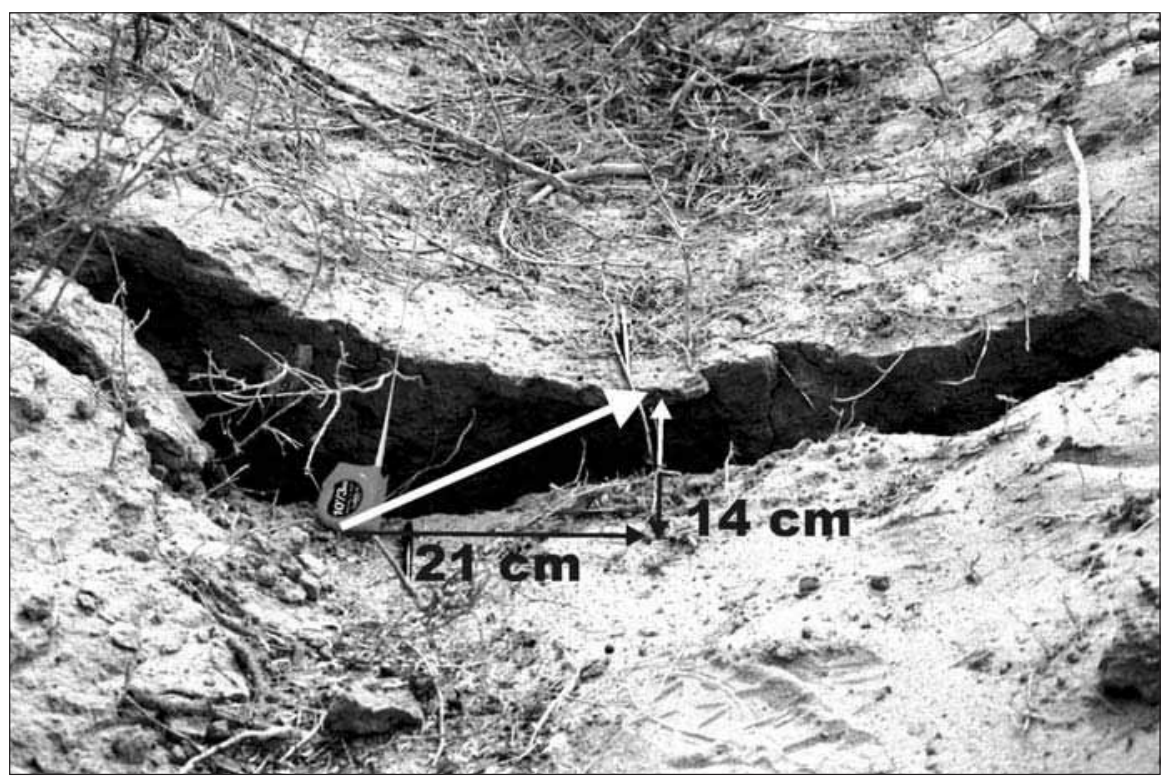

Fig. 15. Close-up of a small gully displaced by the Manfara Fault at $23^{\circ} 27.867^{\prime} \mathrm{N}, 70^{\circ} 22.846^{\prime} \mathrm{E}$; view is to northeast. The gully axis is displaced $21 \mathrm{~cm}$ dextrally and $14 \mathrm{~cm}$ vertically, for a net slip of $25 \mathrm{~cm}$ (white arrow). 
Table I. Dimensions of surface faulting in the 2001 Bhuj earthquake.

\begin{tabular}{ccc}
\hline \hline Dimension & Primary faulting & Secondary faulting \\
\hline Surface rupture length $(\mathrm{km})$ & End-to-end, 0.83 & 15 \\
& Along strike, 0.95 & 35 \\
Maximum displacement $(\mathrm{cm})$ & 35 & $\sim 20$ \\
Average displacement $(\mathrm{cm})$ & $\sim 15$ & 20 \\
\hline
\end{tabular}

sense of slip, we presume that the mounds are also underlain by a decimeter-scale dextral reverse fault zone. Their peculiar morphology may result from the presence of a wet, topographically lower field adjacent to the rupture. We hypothesize that the subvertical dextral rupture plane propagated nearly to the surface, but then «flopped over» toward the field, forming the sinuous thrust scarps that bound the field side of each linear mound. The cross-sections of figs. $11 \mathrm{~b}$ and $13 \mathrm{~b}$ show this inferred geometry, as well as that of the axial tension cracks. The deepest tension cracks were 1.0-1.1 m deep, so any flattening of the fault must have occurred slightly below that depth. Tensional forces in the hanging wall above the fault bend then created the tension cracks. Confirming this subsurface geometry would require trenching, which was beyond the scope of this reconnaissance study.

\subsection{Manfara Fault}

Close to Manfara village, at $23.46^{\circ} \mathrm{N} 70.38^{\circ} \mathrm{E}$, the Manfara Fault ruptured during the earthquake and was first reported by Seeber et al. (2001). The fault strikes NW and runs for $8 \mathrm{~km}$ with a maximum $32 \mathrm{~cm}$ of dextral displacement and $19 \mathrm{~cm}$ of vertical displacement, typically east side up (figs. 14 and 15). Therefore, the fault was interpreted as a «tear fault» in the hanging wall of the master thrust (Rajendran et al., 2001). The surface trace is composed of meter-scale linear segments of different strike that give the rupture a zig-zag appearance (fig. 14). This shape may be inherited from preexisting fractures in the bedrock that underlies the thin alluvium along the fault trace. Sand blows were also reported at many places along this fault. For more details, see Seeber et al., (2001) and Jain and Lettis (2001).

\subsection{Summary of secondary surface faulting}

The secondary surface faulting does not match the orientation of the mainshock focal plane, so it presumably represents some type of tear faulting above the eastern margin of the thrusted block. However, when measuring the dimensions of the 2001 surface faulting we should probably include both the primary and secondary faulting, because in databases such as Wells and Coppersmith (1994) no distinction is made between the two. Table I shows the dimensional parameters of surface faulting, based on our mapping and that of Seeber et al. (2001).

\section{Landslide north of Budharmora village}

The area around the epicenter was intensely affected by lateral spreads in soft alluvial deposits (Rajendran et al., 2002). We studied one particular lateral spread $1 \mathrm{~km}$ north of Budharmora village where the ground slopes about $1^{\circ}$ towards the north. The farmer that owns the field closest to the reservoir shown in fig. 16 reported that he was standing in the field with his family when the 26 January 2001 mainshock struck. He said that members of his family «were pushed up into the air and thrown $3 \mathrm{~m}$ to the northwest» by the mainshock. Water also sloshed out of the reservoir and spilled out of its northwest corner.

Farm fields here were cracked at several places and extensional cracks were developed with an E-W orientation, while 150-200 m north of the extensional cracks, there was a 600 $\mathrm{m}$ long zone of $\mathrm{E}-\mathrm{W}$ compressional ridges (fig. 16). In farm fields, irrigation pipe lines initially emplaced $1.5 \mathrm{~m}$ below the surface appeared severely broken into pieces and were protruding from the surface, overriding each other (Rajendran et al., 2001). Our reconnaissance 
GPS mapping of the deformed area (fig. 16) supports the interpretation of Seeber et al. (2001), Jain and Lettis (2001), and Tuttle et al. (2002) that the feature is a lateral spread landslide. However, the large ground accelerations here may also indicate that the lateral spread overlies a fault (probably the KMF) that moved during the 2001 mainshock, as well as in prehistoric times, as described next.

A French reconnaissance team dug two backhoe trenches across the toe thrust of the lateral spread prior to May 2001 (west trench and east trench in fig. 16), perhaps because shortly after the earthquake, this ridge was thought to represent primary tectonic surface rupture of the KMF. We deepened and relogged the western wall of the west trench to see if fault geometry supported a tectonic or a landslide origin. The log of the trench (fig. 17) shows that the fault planes beneath the compressional ridge flatten about $1.5 \mathrm{~m}$ beneath the ridge crest, and continue south at a dip of about $10^{\circ}$, parallel to bedding in the Holocene sandy alluvium. In reality, the 2001 fault planes were extremely difficult to see once they paralleled bedding, but we infer that the failure plane lay at the base of a gravelly sand unit in the trench wall. Because the fault does not displace obvious stratigraphic markers and deformation beneath the pressure ridge was partly ductile, we could not measure net displacement. A relatively weak soil profile is developed on the sandy alluvium, consisting of ACk1 and ACk2 horizons (weakly organic horizons with Stage I calcium carbonate, after the classification of Gile et al. (1966)) and a Cox horizon (oxidized parent material). This degree of soil development suggests a mid-Holocene age for the alluvial deposit.

The surprising feature in the trench is the strong soil profile at the northern end of the trench, which is bent down to the south and then truncated by an older, north-dipping fault that was not reactivated in 2001 (fig. 17). This soil is developed on a hard gray clay parent material that is also truncated by the older

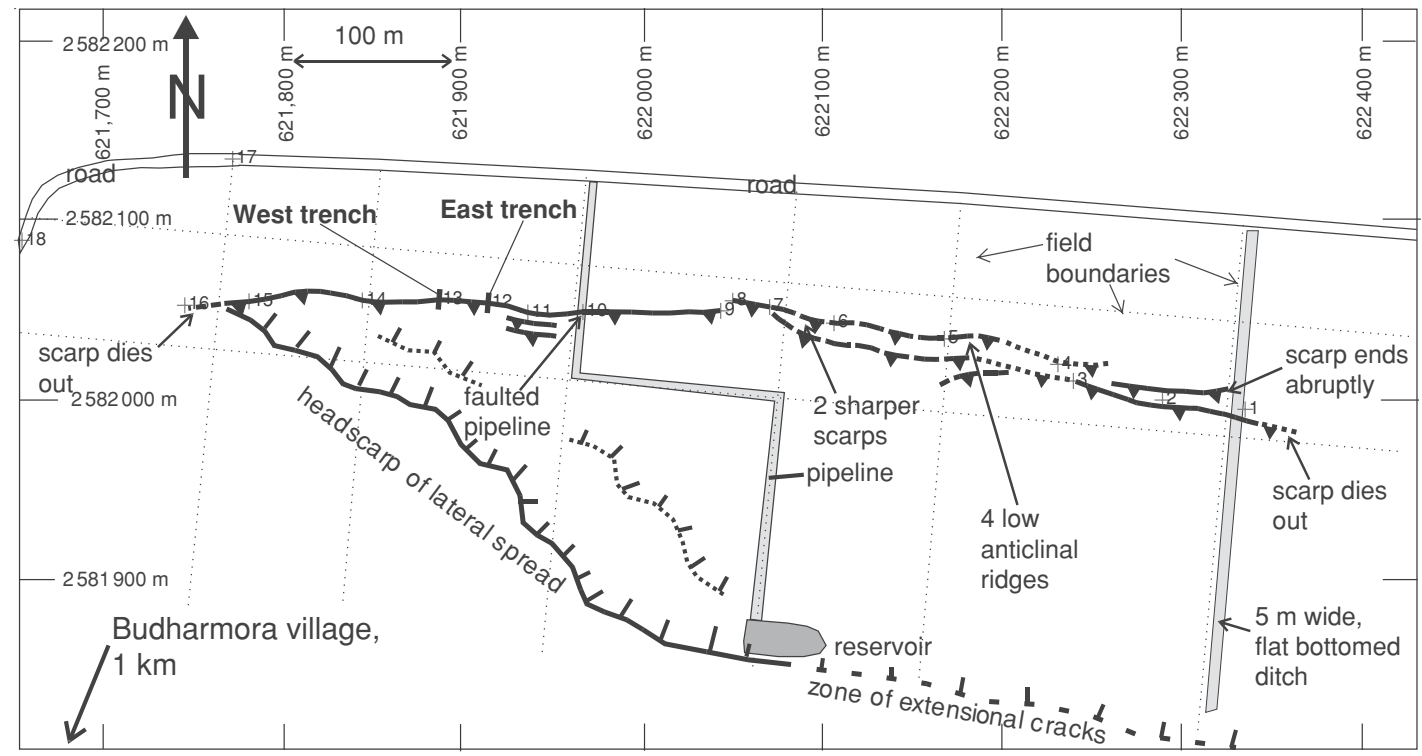

Fig. 16. Reconnaissance GPS map of the lateral spread north of Budharmora village. Coordinates are UTM meters, Zone 42, WGS84 datum. Thick black lines show the margins of the spread, with hachures indicating extensional scarps and teeth indicating compressional scarps or anticlinal ridges. The log of the west trench across the toe thrust is shown in fig. 17. Both extensional and compressional scarps die out to the east. 


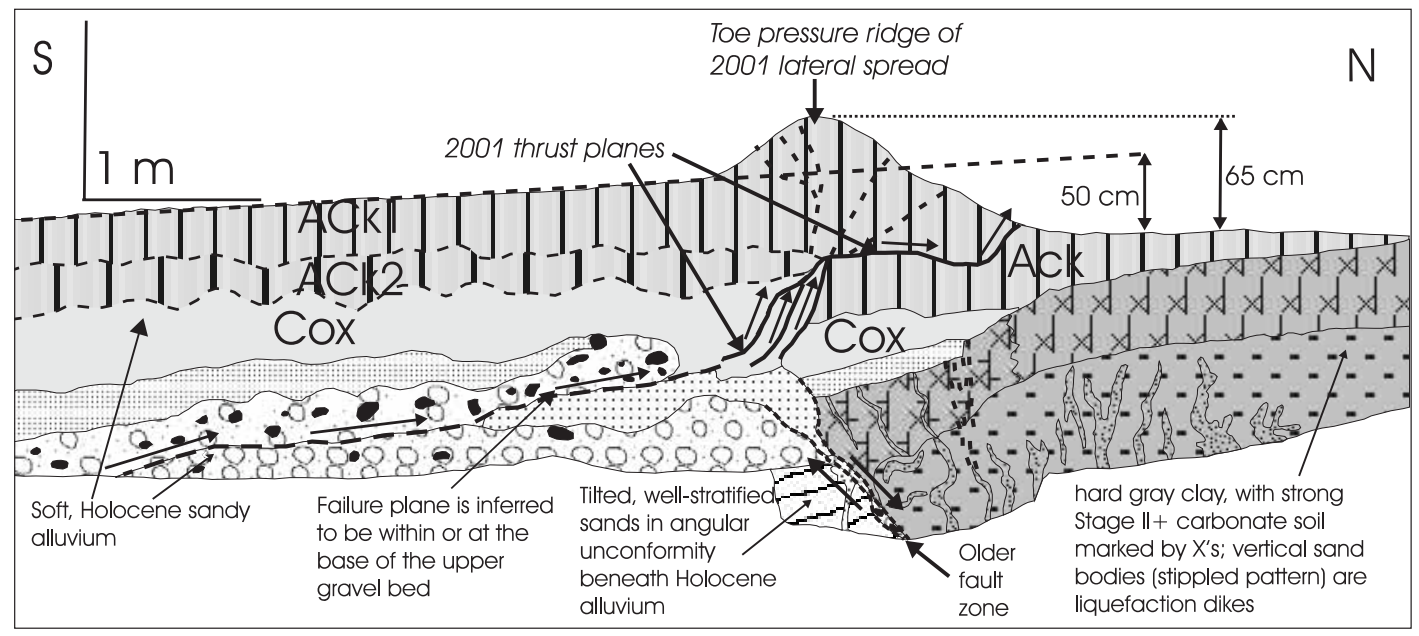

Fig. 17. Log of the western wall of the west trench. The 2001 failure plane is inferred to parallel bedding in the southern part of the trench, and then to rise to the surface in a steplike fashion beneath the toe thrust pressure ridge. An older fault zone of unknown origin and sense of slip underlies the steep section of the 2001 thrust, but was not reactivated in 2001. The 2001 thrust may have been forced to the surface at this location by the buttressing effect of the hard gray clay and overprinted carbonate soil at the northern end of the trench.

fault. The lower half of the clay is riddled with subvertical, rootlike bodies of sand that look like dikes of liquefied sand injected into the clay. However, these sand dikes are also overprinted by soil calcium carbonate, so they were formed in the Middle Holocene or earlier, not in the 2001 earthquake.

The combination of an older fault and older liquefaction features indicates that prehistoric deformation occurred here, but it is unclear exactly when that deformation occurred or whether it was associated with a lateral spread (as occurred in 2001) or with tectonic surface faulting of the KMF. Those questions can only be answered by future studies. It does appear that the 2001 lateral spread failure plane was forced to the surface at this location by the buttressing effect of this hard clay deposit.

\section{Discussion}

To understand the nature of past and present seismicity in a stable continental region such as Kachchh, Quaternary tectonic features are the best indicators. Thrusting in Kachchh is mostly along the pre-Tertiary faults (such as the KMF and KHF) developed in an older extensional regime. Furthermore, the KMF and KHF show geomorphic indicators of segmentation, e.g., sharp changes in orientation of the fault, intersection with branch (transverse) faults, abrupt changes in dip, and changes in net-slip. Knuepfer (1989) concluded such features are very common structural indicators of possible segment boundaries.

The 2001 thrust scarp and the mole tracks we mapped north of Bharodiya village are parallel to the major plane of rupture of the main shock, and are linked to two zones of dextral faulting (the northern dextral fault zone and the Manfara Fault). If these dextral fault zones define the boundary of the north-thrusted block, it follows that the 2001 seismogenic fault which underlies the thrusted block must project to the surface somewhat north of the dextral faults. This constraint appears to rule out the KMF as the seismogenic fault, as does the fact that the 2001 epicenter lies slightly north of the surface trace of the KMF. In addition, the dextral slip on these faults rules out the South Wagad Fault as a candidate. 
Instead, the 2001 mainshock plane must have been a nearly blind thrust parallel to but $30 \mathrm{~km}$ north of the KMF. We say nearly blind because the $0.8 \mathrm{~km}$ long thrust scarp was created, and may represent the only location where primary displacement propagated all the way to the surface. However, based on our reconnaissance data we cannot rule out the possibility that the $M_{w} 7.7$ event was completely blind, and that the mapped thrust scarp was secondary (passive) thrusting induced on a preexisting fault by strong, channeled ground motion extending updip from the seismogenic plane.

\section{Acknowledgements}

The post-earthquake studies, especially the study of the primary surface ruptures of the 2001 Bhuj earthquake, were supported by NSF funding to Boise State University, Idaho, U.S.A. We gratefully acknowledge this support and the cooperative efforts of Jim Zollweg at Boise State.

\section{REFERENCES}

Bendick, R., R. Bilham, E. Fielding, V.K. Gaur, S.E. Hough, G. Kier, M. N. Kulkarni, S. Martin, K. Mueller and M. MuKUL (2001): The 26 January 2001 «Republic Day» earthquake, India, Seismol. Res. Lett., 72, 328-335.

Bilham, R. (1998): Coastal tectonics, Geol. Soc. London, Spec. Publ., 146, 295-319.

BiswAS, S.K. (1981): Basin framework, paleo-environment and depositional history of the Mesozoic sediments of Kutch basin, Western India, Q. J. Geol. Min. Metall. Soc. India, $\mathbf{5 3}$ (1-2), 56-85.

BISWAS, S.K. (1987): Regional tectonic framework, structure and evolution of the western marginal basins of India, Tectonophysics, 135, 302-327.

Gile, L.H. F.F. Peterson and R.B. Grossman (1966): Morphological and genetic sequences of carbonate accumulation in desert soils, Soil Sci., 101, 347-360.

JAIN, S.K. and W.R. LETTIS (2001): Preliminary observations on the origin and effects of the January 26, 2001 Bhuj (Gujarat, India) earthquake, Earthquake Eng. Res. Inst. Spec. Earthquake Rep., EERI Newsletter, 1-16.

KAYAL, JR, R. DE, S. RAM, B.V. SRIRAMA and S.G. GaONKaR (2002): Aftershocks of the 26 January Bhuj earthquake in Western India and its seismotectonic implications, J. Geol. Soc. India, 59 (5), 395-417.

KNEUEPFER, P.L.K. (1989): Implications of the characteristics of end-points of historical surface fault ruptures for the nature of fault segmentation, in Fault Segmentation and Controls of Rupture Initiation and Termination, edited by D.P. Schwartz and R.H. Sibson, U.S. Geol. Sur., Open File Rep., 89-315.
MaLiK, J.N, P.S. SOHONI, R.V. KARANTH and S.S. MERH (1999): Modern and historic seismicity of Kachchh peninsula, Western India, J. Geol. Soc. India, 54, 545-550.

Maurya, D.M, M.G. ThaKkar and L.S. Chamyal (2002): Quaternary geology of the arid zone of Kachchh: terra incognita, in Proc. Ind. Nat. Sci. Acad. (communicated).

Maurya, D.M., S. Bhandari, M.G ThaKkaR and L.S. Chamyal (2003): Late Quaternary fluvial sequences of Southern Mainland Kachchh, Western India: lithostratigraphy and neotectonics implications, Curr. Sci., 84 (8), 1056-1064.

McCalPIN, J.P. (1996): Paleoseismology (Academic Press, New York), pp. 588.

OLdHAM, R.D. (1926): The Cutch (Kachh) earthquake of 16th June 1819 with a revision of the great earthquake of 12th June 1897, Mem. Geol. Surv. India, 46, 71-147

Philip, H., E. Rogozhin, A. Cisternas, J.C. Bousquet, B. BORISOV and A. KARAKHANIAN (1992): The American earthquake of 1988 December 7; faulting and folding, neotectonics and paleoseismicity, Geophys. J. Int., 110, 141-158.

RAJENDRAN, C.P. (2000): Using geological methods for earthquake studies: a perspective from peninsular India, Curr. Sci., 79 (9), 1251-1258.

RAJENDRAN, K and C.P. RAJENDRAN (1999): Seismogenesis in the stable continental interiors: an appraisal based on two examples from India, Tectonophysics, 305, 355-370.

RAJENDRAN, C.P. and K. RAJENDRAN (2001): Characteristics of deformation and past seismicity associated with the 1819 Kutch earthquake, Northwestern India, Bull. Seismol. Soc. Am., 91, 407-426.

RaJendRan, C.P., K. RaJendRan and B. John (1998): Surface deformation related to the 1819 Kachchh earthquake: evidence for recurrent activity, Curr. Sci., 75 (6) 623-626.

RAJENDRAN, K., C.P. RAJENDRAN, M.G. THAKKAR and M.P. TUTTLE (2001): 2001 Kachchh (Bhuj) earthquake: coseismic surface features and their significance, Curr. Sci., 80 (11), 1397-1405.

RajendRan, K. C.P. Rajendran, M.G. ThaKkar and R. Gartia (2002): The sand blows from the 2001 Bhuj earthquake reveal clues on past seismicity, Curr. Sci., 83 (5), 603-610.

Seeber, N., D. Ragona, T. Rockwell, S. Babu, R. Briggs and S.G. WESNOUSKY (2001): Field observations bearing on the genesis of the January 26, 2001 Republic Day earthquake of India resulting from a field survey of the epicentral region, Web Document, Version of February 28, 2001.

Singh, R.P., S. Bhol, A.K. SAHOO, U. RaJ and S. RaVIndRAN (2001): Surface manifestations after the Gujarat earthquake, Curr. Sci., 81 (2), 164-166.

ThaKKar, M.G., D.M MAURYA, R. RACHNA and L.S. ChAMYAL (1999): Quaternary Tectonic history and terrain evolution of the area around Bhuj, Mainland Kachchh, Western India, J. Geol. Soc. India, $\mathbf{5 3}$ (5), 601-610.

ThaKKar, M.G., D.M. MAURYA, R. RACHNA and L.S. CHAMYAL (2001): Morphotectonic analysis of Khari River Basin of Mainland Kachchh: evidence for Neotectonic activity along transverse fault, Bull. Indian Geol. Assoc., 34, 205-220.

Tuttle, M.P., J. Hengesh, K.B. TuCKer, W. LetTis, S.L. DEATON and J.D. Frost (2002): Observations and comparisons of liquefaction features and related effects induced by the Bhuj earthquake, Earthquake Spectra, 18 (suppl. A), 79-100.

WeLls, D.L. and K.J. COPPERSMITH (1994): Empirical relationships among magnitude, rupture length, rupture area, and surface displacement, Bull. Seismol. Soc. Am., 84, 974-1002. 